\title{
DIETARY SODIUM INTAKE AND THE MAIN SOURCES OF SALT IN THE DIET OF YOUNG ADULTS IN LATVIA
}

\author{
Gunta Leite and Daiga Kunkulberga\# \\ Latvia University of Life Sciences and Technologies, 2 Lielā Str., Jelgava, LV-3001, LATVIA \\ \# Corresponding author, daiga.kunkulberga@ Ilu.lv
}

\section{Communicated by Inga Ciproviča}

\begin{abstract}
Scientific studies have regularly confirmed that nowadays the salt consumption through food is too much, and its consumption has to be reduced. The aim of the study was to ascertain the amount of salt consumed per day by 18-35 year-old Latvians as well as to identify the main sources of salt in their diets. The following research methods were used in the study: questionnaire based on an example recommended by the World Health Organisation, sociological research method, bread baking tests, and logically constructive, and statistical research methods. The results of this research showed that the average intake of salt in the diet of 18-35 year-old Latvians was $7.1 \mathrm{~g}$ per day. Of all the respondents, 63\% consumed more than the recommended $5 \mathrm{~g}$ of salt per day, and none of them consumed less than necessary to meet their physiological needs. The results showed that women consumed less salt than men - approximately $6 \mathrm{~g}$ per day, while men consumed $8.2 \mathrm{~g}$ of salt per day. The main sources of salt in the diet of 18-35 year old Latvians were cereals and cereal products, as well as meat and meat products. Among cereal products, the key source of salt was represented by bread and pastry.
\end{abstract}

Key words: salt, sodium reduction, salt in bread.

\section{INTRODUCTION}

Sodium is a mineral that performs important biological functions in the human organism. It participates in ensuring the balance of acids and bases and the balance of water and salts, nerve impulse transmission and a normal heart rhythm as well as in activating digestive enzymes (Campbell et al., 2012). The exchange of sodium takes place in the organism constantly - it is absorbed through food and excreted through urine, sweat, and faeces (Zariňš and Neimane, 2009). The organism contains approximately $70 \mathrm{~g}$ of sodium, and this amount has to be regularly replenished in small quantities (He and MacGregor, 2010; Lejnieks and Kalvelis, 2011). The main source of salt in the diet is processed foods - about $70-75 \%$ of the total intake (Fig. 1) (Lynch et al., 2009).

Excessive salt consumption in the diet is unhealthy, as it has been scientifically proved that high salt consumption is the key factor contributing to higher blood pressure. High blood pressure or arterial hypertension, however, is a risk factor for cardiovascular diseases, which is the key cause of human death in Latvia. In our country, arterial hypertension has become a very important medical and social problem (Lejnieks and Kalvelis, 2011).

The European Commission has established a high-level working group for nutrition and physical activities, one of

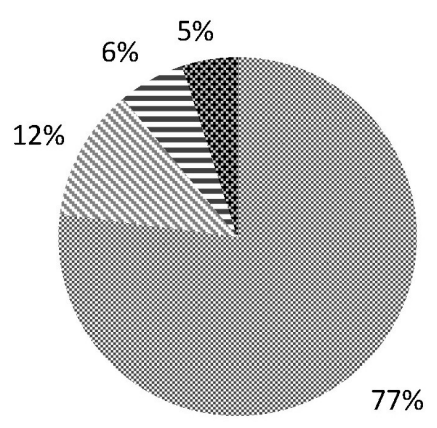

: Industrially produced foodstuffs

Natural foods

$=$ Salt added during meals

Salt added during cooking

Fig.1. The main source of salt in the diet (Lynch et al., 2009),

the tasks of which is to achieve a lower salt content in food products (Anonymous, 2012). The Member States are called for actively implementing salt consumption reduction programmes. According to the European Commission's recommendations, the Member States need to analyse their national data on salt consumption and current salt amounts in foodstuffs, to carry out public informative campaigns aimed at reducing salt consumption and to engage in discussions with food producers. A programme for salt reduction in food is not yet designed in Latvia therefore, such issues are very urgent.

Bread is one of the products that are consumed almost every day. Research has shown that bread is one of the key 
sources of salt in the diet of individuals, and bearing this in mind, a salt consumption reduction plan has been elaborated in many countries, which envisages a $16 \%$ reduction in salt consumption over a period of four years (Salovaara, 2009; Galeone, 2009). According to the recommendations of the European Commission, the amount of salt in producing bakery products should be reduced at least to $1.5 \%$, and for some products - to $1.8 \%$ per $100 \mathrm{~g}$ of flour and the member states have to hold activities for informing the public on the salt content in food and its reduction; therefore, it is important to ascertain the knowledge of consumers on salt consumption and their salt consumption behaviour (Anonymous, 2012).

The aim of the study was to ascertain the amount of salt consumed per day by $18-35$ year-old Latvians as well as to identify the main sources of salt in their diets.

\section{MATERIALS AND METHODS}

To identify the awareness, attitudes, and habits of young individuals regarding salt consumption in Latvia, a questionnaire was used. The one part of a questionnaire with nine questions was designed based on an example recommended by the World Health Organisation (Campbell et al., 2010). The second part of the questionnaire (a 24-hour dietary record) was developed to identify the daily consumption of salt as well as the key sources of salt in diets. The respondents were asked to record what they ate and drank during one day, specifying the composition of the diet and the amount consumed as much in detail as possible. The questionnaire included an explanation on how to calculate the amount of food and salt.

The survey involved 132 respondents (61\% women and 39\% men). The average respondent age was 23 years. The data of the survey were processed with Microsoft Office Excel 2010. The data on the amounts of food and beverages consumed by the respondents were processed with the NutriSurvey programme (retrievable at http://www.nutrisurvey.de/), which revealed the amounts and key sources of sodium consumed. The NutriSurvey programme also calculates the daily consumption of protein, carbohydrates, fat, fibre, calories, and the body mass index (BMI). The data were analysed by SPSS Windows 16.0, significance was defined at the $p \leq 0.05$ level.

\section{RESULTS}

The survey revealed that almost half of the respondents (49\%) rarely added additional salt to their dishes during their meals. Salt was never added to ready dishes by $32 \%$ of the surveyed youth. Of the respondents, $14 \%$ often added additional salt to their dishes during their meals, while 5\% always did it when having a meal. As a positive note, the absolute majority of youth $(81 \%)$ did not add salt to their dishes at all or did it only occasionally.

More than a half or $64 \%$ of the respondents believed that they daily consumed a sufficient amount of salt. Of the sur- veyed youth, $18 \%$ thought they consumed too much salt, while $5 \%$ were convinced that their daily intake of salt was insufficient. A few respondents (1\%) believed they did not daily consume salt enough $(1 \%)$ or, vice versa, they consumed it too much (1\%). Part of the respondents (11\%) did not know how much salt they consumed a day.

An absolute majority of the respondents (87\%) believed that consuming salt too much can cause serious health problems, and only $7 \%$ thought that excessive salt consumption did not create any serious harm to their health. Of the Latvian youth, $6 \%$ did not know what effects could be made by excessive salt consumption on human health.

Of the respondents who assumed that a too high daily intake of salt in the diet could cause serious harm to their health, $18 \%$ did not know what kind of health problems could emerge. Of the respondents, $29 \%$ could indicate all the health problems, which emerge owing to excessive salt consumption, given in four reply options: high blood pressure, osteoporosis, stomach cancer, and kidney stones. However, $3 \%$ believed that excessive salt consumption did not cause any of the mentioned health problems. Of the respondents, $33 \%$ believed that it was important and $8 \%$ were convinced that it was very important to limit or reduce salt consumption (Fig. 2). Almost one of five young individuals (19\%) believed that it was important for them to limit or reduce salt consumption; however, most of the respondents (40\%) admitted that they had not thought about it.

More than a half of the respondents (55\%) did not do any activities in their daily life to limit or reduce their salt consumption. Fewer respondents $(40 \%)$ thought about limiting their salt consumption in their daily diet and did some activities. Of the surveyed youth, $5 \%$ had never thought of it.

After summarising data from questionnaire on the respondents' height and body weight and calculating the body mass index (BMI), it was found that most of them $(75 \%)$ had a normal weight $(\mathrm{BMI}=18.5-24.9)$, while $16.7 \%$ were overweight (BMI = 25.0-29.9). Unfortunately, part of the youth $(4.5 \%)$ already had obesity (BMI > 30). Not only obesity but also an insufficient body weight (BMI < 18.5), which was identified for $3.8 \%$ of the surveyed youth, is a risk factor for health.

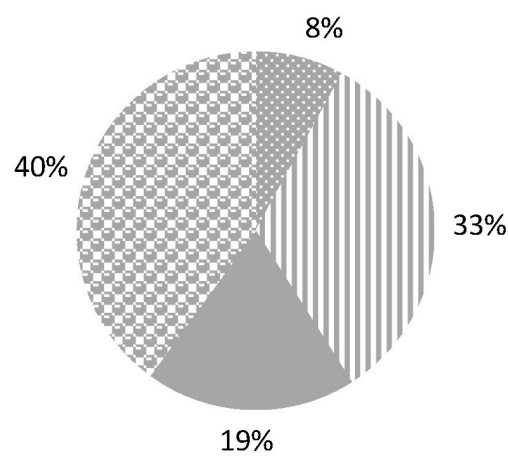

very important
II important
unimportant
never thought about it

Fig. 2. How important is it for you to limit/reduce salt consumption in your diet? 
DAILY INTAKE OF NUTRITION BY 18-35 YEAR-OLD INDIVIDUALS IN LATVIA

\begin{tabular}{l|c|c|c}
\hline & Intake, g & Intake, E \% & $\begin{array}{c}\text { Recommended*, } \\
\text { E \% }\end{array}$ \\
\hline Protein & 93 & 19 & $10-15$ \\
Fat & 93 & 42 & $25-30$ \\
Carbohydrates & 193 & 39 & $55-60$
\end{tabular}

* Recommended energy and nutritional values for residents of Latvia (2008). Ministry of Health of the Republic of Latvia, p. 5. Available from: http://www.vm.gov.lv/images/userfiles/ieud.pdf (accessed 15 August 2016).

On average, the youth consumed $1982 \mathrm{kcal}, 93 \mathrm{~g}$ protein, 93 $\mathrm{g}$ fat and $193 \mathrm{~g}$ carbohydrates in their daily diet. The youth consumed protein slightly more than required, their intake of fat was considerably higher than recommended, whereas their daily intake of carbohydrates was insufficient (Table $1)$.

The necessary amount of fibre in the diet of adults equals 30-35 g per day (Anonymous, 2008b); yet, according to the survey, the respondents consumed, on average, $18.5 \mathrm{~g}$ fibre a day, which was less than recommended.

The average daily intake of $\mathrm{Na}$ by the youth aged 18-35 was $2.8 \mathrm{~g}$, which was equivalent to $7.1 \mathrm{~g}$ salt $(\mathrm{NaCl})$. Compared with men, women consumed less salt; their daily intake was $6.0 \mathrm{~g}$, while men consumed $8.2 \mathrm{~g}$ a day. The highest daily intake of $\mathrm{NaCl}$ by women was $20 \mathrm{~g}$ and $23 \mathrm{~g}$ by men. Of all the respondents, $63 \%$ consumed more than the recommended $5.0 \mathrm{~g}$ of $\mathrm{NaCl}$ a day.

A comparison of the data for women and men showed that the men more often in their daily life consumed salt more than recommended. Of the surveyed men, $77 \%$ consumed more than $5.0 \mathrm{~g} \mathrm{NaCl}$ per day, while slightly more than half of the women, $54 \%$, consumed more than $5.0 \mathrm{~g}$ of $\mathrm{NaCl}$ per day.

The respondents who gave an answer to the question "How much salt, in your opinion, do you daily consume" that they consumed enough salt, however, actually consumed on average $6.7 \mathrm{~g}$ of sodium chloride a day, which is equivalent to $2.68 \mathrm{~g}$ of sodium and is more than the recommended daily intake of salt (Table 2). The youth who believed that they consumed too much salt, consumed, on average, $6.6 \mathrm{~g}$ of salt a day, which is equivalent to $2.65 \mathrm{~g}$ sodium and exceeds the recommended daily intake of salt; yet, those individuals who thought they consumed too much salt, consumed, on average, $4.7 \mathrm{~g}$ of salt per day (1.89 $\mathrm{g}$ sodium), which did not exceed the recommended daily intake of salt. The respondents who believed that they consumed too little salt, actually consumed, on average, $4.5 \mathrm{~g}$ of salt per day (1.81 g sodium), which not exceed the recommended daily intake of salt. The survey also revealed that the youth who were convinced that they consumed too little salt during the day, in reality consumed two times more salt than recommended, $10.8 \mathrm{~g}$, which is equivalent to $4.33 \mathrm{~g}$ sodium. However, the
REAL DAILY INTAKE OF SODIUM AND SALT IN COMPARISON AND THE SUBJECTIVE OPINION ABOUT THE DAILY CONSUMPTION OF SALT

\begin{tabular}{l|c|c|c|c}
\hline \multirow{2}{*}{$\begin{array}{c}\text { How much salt, } \\
\text { in your opinion, } \\
\text { do you daily } \\
\text { consume? }\end{array}$} & \multicolumn{2}{|c|}{$\begin{array}{c}\text { Real daily intake of } \\
\text { of sodium, }\end{array}$} & \multicolumn{2}{c}{$\begin{array}{c}\text { Real daily intake } \\
\text { of salt, g }\end{array}$} \\
\cline { 2 - 6 } & average & $\begin{array}{c}\text { minimum- } \\
\text { maximum }\end{array}$ & average & $\begin{array}{c}\text { minimum- } \\
\text { maximum }\end{array}$ \\
\hline Very too much & 1.89 & 1.89 & 4.7 & 4.7 \\
Too much & 2.65 & $0.84-9.19$ & 6.6 & $4.3-11.3$ \\
Enough & 2.68 & $0.61-8.95$ & 6.7 & $1.5-22.4$ \\
Not enough & 1.82 & $0.68-2.98$ & 4.5 & $1.7-7.4$ \\
Very much not & 4.33 & 4.33 & 10.8 & 10.8 \\
enough & & & & $1.7-17.1$ \\
Don't know & 3.79 & $0.66-6.85$ & 9.5 &
\end{tabular}

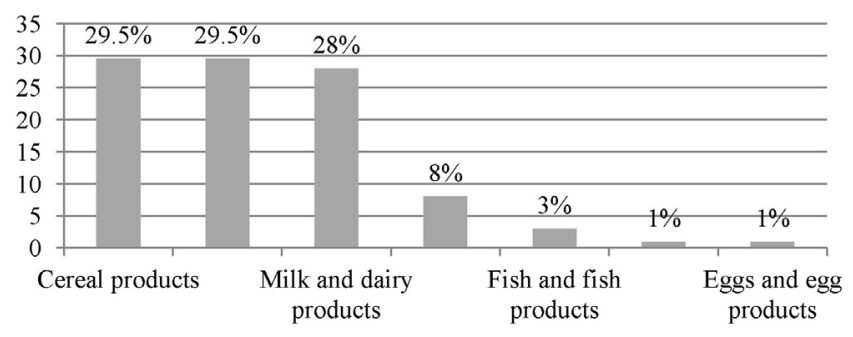

Fig. 3. Key sources of salt in the diet by 18-35 years-old individuals in Latvia.

youth who did not know how much salt they consume per day, consumed twice as much as recommended $(9.5 \mathrm{~g}$ of salt or $3.80 \mathrm{~g}$ of sodium).

The key sources of salt for Latvian residents aged 18-35 were grain products (bread, breakfast cereals, biscuits, cakes etc.), which provided $29.5 \%$ of the daily intake of salt, as well as meat and meat products that also supplied $29.5 \%$ of the total daily intake of salt (Fig. 3). The next most significant source of salt was dairy products, mainly cheese, which provided $28.0 \%$ of the daily salt intake. Vegetables provided $8.0 \%$ of the daily salt intake for the respondents; we found that young people often consumed potato chips. A small amount of salt was supplied also by fish products $(3.0 \%)$ as well as legumes like beans and peas $(1.0 \%)$ and cooked and fried eggs (1.0\%). Among cereal products, the key source of salt was represented by bread and flour products $(67.0 \%)$, followed by breakfast cereals and oatmeal porridge $(18.0 \%)$ as well as biscuits, cakes and bread rolls $(15.0 \%)$.

\section{DISCUSSION}

Sodium is a nutrient that is necessary for humans and that is absorbed mainly through the consumption of salt. In daily life, humans need a small amount of salt - about 1.3--1.5 $\mathrm{g}$ per day; yet, nowadays in most countries around the world, including Latvia, the amount of salt consumed is often 6-8 times greater than recommended (Anonymous, 2012). This results in a number of health problems, first of 
all, high blood pressure, which is a risk factor for cardiovascular diseases (Campbell et al., 2012).

In Latvia, the salt intake recommended by the Ministry of Health is set at not more than $5 \mathrm{~g}$ of dietary salt per day (Anonymous, 2008a), while individuals aged 60 and over should not consume more than $3 \mathrm{~g}$ of salt (1200 mg sodium) per day, which is approximately two thirds of a teaspoonful (Anonymous, 2008b; Anonymous, 2007). The mentioned amounts comprise not only the salt added during cooking or when eating meals but also the salt that is present, for example, in cheese, bread, and meat products. As found in our research, an absolute majority of the youth $(81 \%)$ preferred adding no salt to their dishes or added the salt occasionally; yet, among those who used to add salt to their dishes, there were a lot of youths who rarely tasted their dishes or even did not taste the dishes before adding additional salt. As noted in other studies in low-to-middle income countries where populations may have limited access to processed foods, salt added at home, in cooking, or at the table, accounts for the majority of dietary salt (Campbell et al, 2012). More than a half or $64 \%$ of the respondents believed that they daily consumed a sufficient amount of salt.

The research found that $87 \%$ of the surveyed youth in Latvia know that the daily overconsumption of salt in their diet could cause serious health problems. Kidney stones were a disease best known by the youth. Of the respondents, $40 \%$ had never thought of limiting or reducing salt consumption in their daily diets, while almost one in five $(19 \%)$ believed that it was important to them.

The Latvian Society of Cardiology suggests consuming not more that 5-6 g of salt per day (Ërglis et al., 2007), while the European Society of Cardiology recommends a salt intake of not more than $5 \mathrm{~g}$ per day (Perk et al., 2012). A similar amount of salt is recommended by the World Health Organisation (WHO) as well (Anonymous, 2010; Anonymous, 2011).

According to a study "Comprehensive Investigation into Food Consumption by the Population of Latvia 2007-2009" done by the National Diagnostic Centre and the Food and Veterinary Service, the average intake of dietary salt with food by persons aged 7 to 36 years of Latvia was 6.9 g per day (Anonymous, 2009). The results of both studies are similar and do not contradict each other.

As found in research investigations by foreign scientists, a higher intake of salt in the daily diet was observed among men (Elliott and Brown, 2007). Similar results were obtained in a study conducted by the National Diagnostic Centre of Latvia (Anonymous, 2009).

A study conducted in the United Kingdom revealed that if the salt consumed when eating meals or during cooking as well as when eating outside the home is not taken into account, the intake of salt from grain products (bread, breakfast cereals, biscuits, cakes etc.) make up $38 \%$ of the of the daily amount of salt consumed, while the second most sig- nificant source of salt in the diet, accounting for $21 \%$, relates to meat and meat products (Syrad et al, 2016). A similar trend is observed in the United States of America, where the key source of salt in the diet is from grain products, followed by meat and its products (Brown et al., 2009). The key sources of salt in the diets of Latvian residents aged 18-35 are cereal products as well as meat and its products. In Finland bread also is a major source of salt (25-35\%) (Salovaara, 2009). If an adult consumes on average $250 \mathrm{~g}$ of bread per day, the salt content of which is $1.2 \%$, the salt intake is $3.0 \mathrm{~g}$, which accounts for $50 \%$ of the recommended daily salt portion. If bread contains $1.6 \%$ salt, the salt intake is $4.0 \mathrm{~g}$ by consuming $250 \mathrm{~g}$ of bread, which accounts for $80 \%$ of the recommended daily salt portion (Kunkulberga and Mūrniece, 2013). Among cereal products, the key source of salt is bread and flour products. Other scientists emphasise that salt is added to food bought in almost all supermarkets - not only to canned food and sausages, but also to bread, spaghetti, cheese, and even yogurt (Großklaus et al., 2009). Today, at a time when we use a diet rich in manufactured products and food saturated with salt, it is necessary to hold regular public awareness campaigns and discussions with food producers for the reduction of the salt content of food. To achieve a reduction in population salt intake, the food industry needs to make a gradual and sustained reduction in the amount of salt added to all foods (Galeone, 2009; Lynch et al., 2009).

\section{CONCLUSION}

Youth in Latvia have intakes of fat, protein and $\mathrm{NaCl}$ that are higher than recommended levels and potentially increase for the future the risk of obesity and elevated blood pressure. The majority of the salt consumers eat is in everyday foods so it is important to check labels and choose lower salt options. There is need to hold mass media campaigns, and co-operation with the food industry regarding the reduction of salt content in food.

\section{ACKNOWLEDGEMENTS}

This research was supported by the National Research Programme "Agricultural Resources for Sustainable Production of Qualitative and Healthy Foods in Latvia" (AgroBioRes) (2014-2017), Project No. 4 "Sustainable use of local agricultural resources for qualitative and healthy food product development" (FOOD).

\section{REFERENCES}

Anonymous (2007). Veselìga uztura ieteikumi cilvēkiem, kas vecāki par 60 gadiem [Healthy eating guidelines for people after 60]. Ministry of Health of the Republic of Latvia. 6 pp. Available from: http://www.vm.gov.lv/images/ userfiles/ieteikumi_veciem_cilvekiem.pdf (in Latvian) (accessed 22 August 2016).

Anonymous (2008a). Ieteicamās enerǵijas un uzturvielu devas Latvijas iedzìvotājiem [The recommended energy and nutrient intakes for Latvian residents] Ministry of Health of the Republic of Latvia. 5 pp. Available from: http://www.vm.gov.lv/images/userfiles/ieud.pdf (in Latvian) (accessed 22 August 2016). 
Anonymous (2008b). Veselīga uztura ieteikumi pieaugušajiem (2008) [Healthy eating guidelines for adults]. Ministry of Health of the Republic of Latvia. 12 pp. Available from:

http://www.vm.gov.lv/images/userfiles/uztura_ieteikumi_pieaugu sajiem.pdf (in Latvian) (accessed 22 August 2016).

Anonymous (2009). Latvijas iedzìvotāju visaptverošais pārtikas patēriņa pètījums 2007-2009 [The National Food Consumption Survey of Latvia 2007-2009, (2009)]. National Diagnostic Centre of Food and Veterinary Service. 115 pp. Available from:

http://www.pvd.gov.1v/lat/augj_izvlne/iedzvotjiem_un_uzmjiem/ ptjumi_un_apskati/ptjums_quotlatvijas_nacionlais (in Latvian) (accessed 22 August 2016).

Anonymous (2010). U.S. Department of Agriculture, U.S. Department of Health and Human Services. Dietary Guidelines for Americans, 2010. $7^{\text {th }}$ Edition, Washington, DC: U.S. Government Printing Office. 97 p. Available from:

http://www.health.gov/dietaryguidelines/dga2010/dietaryguidelines 2010.pdf (accessed 17 July 2016)

Anonymous (2011). Review and updating of current WHO recommendations on salt/sodium and potassium consumption: Call for Public Comments. Geneva, Switzerland: World Health Organization. 8 pp. Available from: http://www.who.int/nutrition/events/NUGAG_dietandhealth_subgroup _call_public_comment_scope_of_Na_K.pdf (accessed 22 August 2016).

Anonymous (2012). European Commission: Implementation of the EU Salt Reduction Framework Results of Member States survey. Available from: http:// ec.europa.eu/health/nutrition_physical_activity/docs/salt_report_en.pdf (accessed 12 August 2016).

Brown, I. J, Tzoulaki, I., Candeias, V., Elliott, P. (2009). Salt intakes around the world: Implications for public health. Int. J. Epidemiol., 38, 791-813.

Campbell, N., Cappuccio, F., Barquera, S. et al. (2010). Protocol for population level sodium determination in 24-hour urine samples. Prepared by WHO/PAHO Regional Expert Group for Cardiovascular Disease Prevention through Population wide Dietary Salt Reduction. 40 pp. Available from: http://new.paho.org/hq/dmdocuments/2010/pahosaltprotocol.pdf (accessed 19 August 2016)

Campbell, N. R. C., Johnson, J. A., Campbell, T. S. (2012). Sodium Consumption: An Individual's Choice? Int. J. Hypertension, 2012, Article ID 860954, 6 pp. Available from: http://dx.doi.org/10.1155/2012/860954 (accessed 16 August 2016).

Elliott, P., Brown, I. (2007). Sodium intakes around the world. Background document prepared for the Forum and Technical meeting on Reducing Salt Intake in Populations (Paris 5-7th October 2006). World Health Organiza- tion. $85 \mathrm{pp}$. Available from:

http://www.who.int/ dietphysicalactivity/Elliot-brown-2007.pdf (accessed 23 August 2016).

Ērglis, A., Kalvelis, A., Lejnieks, A., Dzērve, V., Latkovskis, G., Mintāle, I., Zakke, I., Rasa, I. (2007). Kardiovaskulāro slimību (KVS) profilakses vadlīnijas [Guidelines on cardiovascular disease prevention]. Rìga: Latvijas Kardiologu biedrība. 126 lpp. Available from:

http://new.paho.org/hq/dmdocuments/2010/pahosaltprotocol.pdf (in Latvian) (accessed 22 August 2016).

Galeone, D. (2009). Italy: salt reduction initiatives for bread. Available from: http://ec.europa.eu/health/nutrition_physical_activity/docs/ ev20091021_galeone_en.pdf (last accessed 15 August 2016).

Großklaus, R., Lampen, A., Wittkowski, R. (2009). Für und Wider einer Salzreduktion in der Gesamtbevölkerung. Tagungsband zum Expertengespräch im Bundesinstitut für Risikobewertung am 15. Oktober 2009 in Berlin. Available from:

http://www.ages.at/ages/ernaehrungssicherheit/thema-ernaehrung/salzko nsum-und-bluthochdruck/ (last accessed 15 August 2016).

He, F. J., MacGregor G. A. (2010). Reducing population salt intake worldwide: from evidence to implementation. Progr. Cardiovasc. Dis., 52, 363-382.

Kunkulberga, D., Mūrniece, E. (2013). Salt and bread: Latvia's experience. Proc. Latvian Acad. Sci., Section B, 67 (4/5), 383-388.

Lejnieks, A., Kalvelis, A. (2011). Viss par sāli [All About Salt]. Rīga: Latvijas Hipertensijas biedrïba. 33 lpp. (in Latvian).

Lynch, E. J., Dal Bello, F., Sheehan, E. M., Cashman, K. D., Arendt, E. K. (2009). Fundamental studies on the reduction of salt on dough and bread characteristics. Food Res. Int., 42, 885-891.

Perk, J., De Backer, G., Gohlke, H., Graham, I., Reiner, Z., Verschuren, M., , C., Benlian, P., Boysen, G., Cifkova, R., Deaton, C., Ebrahim, S., Fisher, M., Germano, G. Hobbs, R., Hoes, A., Karadeniz, S., Mezzani, A, Prescott, E., Ryden, L., Scherer, M., Syvänne, M., Scholte op Reimer, W. J, Vrints, C., Wood, D., Zamorano, J. L., Zannad, F. (2012). European Guidelines on cardiovascular disease prevention in clinical practice (version 2012). Eur. Heart J., 33, 1635-1701.

Salovaara, H. (2009). Technologies of salt reduction in bread: Issues, problems and solutions. Available from: https://ec.europa.eu/health/sites/ health/files/nutrition_physical_activity/docs/ev20091021_salovaara_en.pdf (accessed 22 September 2016).

Syrad, H., Llewellyn, C. H., Jaarsveld, C. H. van, Johnson, L., Jebb, S. A., Wardle, J.(2016). Energy and nutrient intakes of young children in the UK: findings from the Gemini twin cohort. Brit. J. Nutr., 115, 1843-1850.

Zariņš, Z., Neimane, L. (2009). Uztura mācība [Nutrition]. Rīga: LU Akadēmiskais apgāds. 464 lpp. (in Latvian).

Received 13 January 2017

Accepted in the final form 10 November 2017

\section{SĀLS PATĒRINSŠ UN GALVENIE TĀ AVOTI JAUNU CILVĒKU UZTURĀ}

Nātrijs ir minerālviela, kas veic svarīgas bioloğiskas funkcijas cilvēka organismā, tomēr pārmērīga sāls lietošana uzturā ir nevēlama. Pētījuma mērḳis ir noskaidrot dienā patērēto sāls daudzumu 18-35 gadus vecu Latvijas iedzīvotāju vidū, kā arī identificēt galvenos sāls avotus uzturā. Lai noskaidrotu, vai cilvēki spēj sajust sāls daudzuma atškirības maizē, veikta kviešu maizes sensorā novērtēšana paraugiem ar dažādu sāls saturu. Pētījuma rezultāti rāda, ka vidējais diennaktī uzṇemtais sāls daudzums 18-35 gadus vecu Latvijas iedzīvotāju uzturā ir 7,1 g. 63\% no visiem aptaujātajiem uzṇem vairāk par ieteicamajiem 5 g sāls dienā, un neviens no aptaujātajiem respondentiem dienas laikā neuznem mazāk sāls par fizioloğiski nepieciešamo daudzumu. Rezultāti liecina, ka sievietes sāli uzṇem mazāk nekā vīrieši, diennaktī patērējot $6,0 \mathrm{~g}$ sāls, savukārt vīrieši uzṇem 8,2 g sāls dienā. Aptaujas rezultāti un aprēḳini rāda, ka galvenie sāls avoti 18-35 gadus vecu Latvijas iedzīvotāju uzturā ir graudaugu produkti, kā arī gạ̣a un galas produkti. No graudaugu produktiem galvenais sāls avots ir maize un maizes izstrādājumi. 